\title{
THE BRITISH JOURNAL OF EXPERIMENTAL BIOLOGY
}

Edited by J. GRAY

WITH THE ASSISTANCE OF

F. A. E. CREWS

\begin{tabular}{llll} 
J. BARCROFT & J. B. S. HALDANE & J. S. HUXLEY & W. H. PEARSALL \\
A. J. CLARK & J. T. HOG.BEN & C. F. A. PANTIN & J. T. SAUNDERS \\
\hline
\end{tabular}

VoLUMre V, No 4

Price $12 s 6 d$ net

JUNE 1928

\section{CONTENTS}

A. Lipschutz, New Developments in Ovarian Dynamics and the Law of Follicular Constancy.

L. Hogben and J. vaN DER Lingen, On the Occurrence of Haemoglobin and of Erythrocytes in the Perivisceral Fluid of a Holothurian.

L. T. Hogren and L. Mirvish, The Pigmentary Effector System V. The Nervous Control of Excitement Pallor in Reptiles.

I. L. DeAn, M. E. SHAW and M. A. TazeraAr, The Effect of a Temperature Gradient on the Early Development of the Frog.

J. GraY, The Effect of Dilution on the Activity of Spermatozon.

J. Gray, The Senescence of Spermatozoa.

J. GRAY, The Effect of Egg-secretions on the Activity of Spermatozon.

A. C. Chaddhuri, The Iodine Content of the Thyroid of the Fowl with Reference to Age and Sex.

A. S. Parkes, The Length of the Oestrous Cycle in the Unmated Normal Mouse: Records of One Thousand Cycles.

A. W. Greenwood and A. C. Chaudhuri, An Experimental Study on the liffect of Thyroxin upon Sexual Differentiation in the Fowl.

A. D. Hobson, The Effect of Electrolytes on the Muscle of the Fore-Gut of Dytiscus marginalis, with Special Reference to the Action of Potassium.

TNDEX of SUb.JECTS. Index of AUthors.

Volume VI, No. 1

Price $12 s 6 d$ net

September, 1928

CONTENTS

J. G. H. Frew, A Technique for the Cultivation of Insect Tissues.

J. T. Cunningham, On Ligature of the Vas Deferens in the Cat and Researches on the Efferent Ducts of the Testis in Cat, Rat and Mouse.

J. GRAY, The Rôle of Water in the Evolution of the Terrestrial Vertebrates.

F. C. Steward, An Experimental Examination of the Evidence for the Presence of Phosphatides in the Limiting Surface of the Living Protoplast.

H. M. Evans and G. C. C. Damant, Observations on the Physiology of the Swim Bladder in Cyprinoid Fishes.

J. R. BAKER, A New Type of Mammalian Intersexuality.

A. D. Hobson, The Action of Isotonic Salt Solutions on the Unfertilised Eggs of Thalassema neptuni.

W. M. Davis, The Effect of Variation in Relative Humidity on Certain Species of Collembola.

A. Zoond and D. Sunme, The Relation of Electrolytes to the Cardiac Rhythm of Palinurus (Jasus) lalandii and Octopus horridus.

Subscription price 40 s net per volume.

\section{Published for The Company of Biologists Limited by THE CAMBRIDGE UNIV̈ERSITY PRESS}

LoNDON: Fetter Lane, E.c. 4 
$\mathrm{OF}$

\title{
MICROSCOPICAL SCIENCE
}

\author{
EDITOR : \\ EDWIN S. GOODRICH, M.A., F.R.S.
}

Contents of No. 284-New Series.

Part TV, Volume 71, April, 1928.

\section{MEMOIRS}

Hermaphroditism in Rhyscotus, a Terrestrial Tsopod. By H. G. JACKson, D.Sc. (With 6 Text-figures.)

The Roles of the Nurse-cells, Oocytes and Follicle-cells in Tenthredinid Oogenesis. By Professor A. D. Peacock, D.Ss., F.R.S.E., and R. A. R. Gresson, B.Sc. (With Plates 40-2 and 1 Text-figure.)

The Muscles of the adult Honey-bee (Apis mellifera L.) By G. D. Morison, B.Sc.(Lond.). With 41 Text-figures.)

Sex Studies on Schistosoma japonicum. By A. E. Severinghaus. With Plates 43-6 and 1 Text-figure.)

Conten'ts of No. 285-New Sierims.

Part I, Volume 72, August, 1928.

MEMOIRS

On the Development of Botrylloides, and its bearings on some Morphological Problems. By Sylvia L. Garstang, M.A.(Oxon), and W. Garstang, M.A., D.Sc.(Oxon)." With Plates $1-3$ and 4 Text-figures.)

The Morphology of the Tunicata, and its bearings on the Phylogeny of the Chordata. By W. Garstang, M.A., D.So. (With 13 Text-figures.)

Contents of No. 286-New Series.

Part II, Volume 72, October, 1928.

\section{MENOTRS}

Reconstruction of Daughter Nuclei and the individuality of Chromosomal Vesicles during Interkinesis. By J. MCA. Kater. (With Plates 4 and 5.)

Feeding Organs and Feeding Habits of Autolytus Edwarsi St. Joseph. Studies on the Syllidae, 1.). By Yô K. Orada, Naba, Hyogo-Ken (Japan). With 10 Textfigures.

Experimental Studies on the Histology of the Mammalian Thymus. By Rutr. Deanesly, B.A., B.Sc. (With Plates 6-12.)

Studies in the Origin of Yolk. I. Oogenesis of the Spider, Crossopriza lyoni Blackwall. By Vishwa Nath, M.Sc., Ph.D.(Cantab.). (With 23 Text-figures.)

Yolk-Absorption in Loligo and the function of the embryonic liver and pancreas. By Ad. Portann, Ph.D.(Basle) and Anna M. Bidder, B.A.(Cambridge): (With Plates 13-19.)

Reactions of Gammarus to Injury and Disease, with notes on some Micro. sporidial and Fungoid Diseases. By Helen Pixelr Goodrich, M.A.(Oxon), D.Sc.(Lond.). (With Plate 20.)

Subscription Price per Volume, $£ 3$ 3s net.

Single Parts $£ 1$ ls net.

OXFORD LINIVERSITY PRESS

AMEN HOUSE, LONDON, E.C. 4 


\section{PUBLICATIONS OF THE ASSOCIATION.}

\section{Journal of the Marine Biological Association of the United Kingdom.}

Old Series. - No. 1, $1887 . \quad$ No. 2, 1888.

New Series.-Volumes I to XV. 1889-1928.

Separate numbers (generally 4 to one volume), in wrappers, from $1 s$. to $12 s$. $6 d$. each, according to size.

\section{THE DINOFLAGELLATES OF NORTHERN SEAS}

BY

M. V. LEBOUR, D.Sc., F.Z.S.

1925. Price 12s. 6d. net.

\section{PLYMOUTH AQUARIUM GUIDE BOOK}

BY

E. W. SEXTON

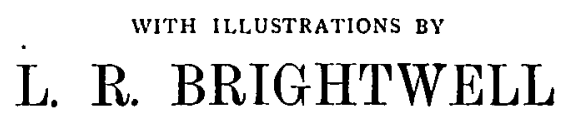

AN ACCOUNT IN POPULAR LANGUAGE OF FISHES AND OTHER ANIMALS LIVING IN THE SEA.

Price 1s. Post-free, $1 s .3 d$.

ALL PUBLICATIONS MAY BE OBTAINED FROM THE DIRECTOR, MARINE BIOLOGICAL LABORATORY, PLYMOUTH.

London Agents : Messrs. Dulau \& Co., Ltd., 32 Old Bond St., Piccadilly. W. 1. 


\section{CONTENTS OF NEW SERIES, Vol. XV., No. 3.}

PAGE

1. The Laboratory of the Marine Biologrcal association at Plymouth. By E. J. Allen and H. W. Harvey. With Figures 1 to 7 and Plans $I$. to VII.

2. List of Publications Recording the Results of Researches CARRIED OUT UNDER THE AUSpices of the MARINe BIOlogical Association of the Uniten Kingdom in their Laboratory at Plymouth or on the North Sea Coast from 1886-1927 753

3. The Vertical Distribution of Marine Macroplankton. Vili. Further Observations on the Diurnal Behayiour of the Pelagic Young of Teleostean Fishes in the Plymotth Area. By F. S. Russel. With 6 Figures in the Text . . . 829

4. Observations on Patella vulgata. Part I. Sex-Phenomena, Breeding and Shell-Growth. By J. H. Orton . 851

5. Observations on Patella vulgata. Part II. Rate of Growth

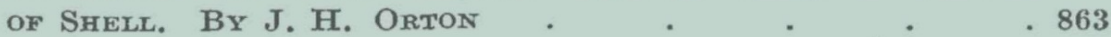

\section{NOTICE.}

The Council of the Marine Biological Association wish it to be understood that they do not accept responsibility for statements published in this Journal excepting when those statements are coutained in an official report of the Council.

\section{TERMS OF MEMBERSHIP.}

Annual Members.

Life Members

Founders

Governors

$$
\begin{aligned}
& \text { - per annum } \quad \begin{array}{ccc}
\text { s. } & \boldsymbol{d} \\
\hline & 1 & 0
\end{array} \\
& \text { Composition Fee } 15 \quad 15 \quad 0 \\
& \text {. } 100 \quad 0 \quad 0 \\
& \text {. } 50000
\end{aligned}
$$

Members of the Association have the following rights and privileges : they elect annually the Officers and Council; they receive the Journal of the Association free by post; they are admitted to view the Laboratory at Plymouth, and may introduce friends with them; they have the first claim to rent a place in the Laboratory for research, with use of tanks, boats, \&c. ; and have access to the books in the Library at Plymouth.

All correspondence should be addressed to the Director, The Laboratory, Plymouth. 